\title{
AXONAL TRANSPORT AND TURNOVER OF PROLINE- AND LEUCINE-LABELED PROTEIN IN THE GOLDFISH VISUAL SYSTEM
}

\author{
J. H. Neale,' J. S. Elam, ${ }^{2}$ E. A. Neale ${ }^{1}$ and B. W. Agranoff \\ Neuroscience Laboratory, The University of Michigan, Ann Arbor, MI 48104, U.S.A.
}

(Received 16 January 1974. Accepted April 1 1974)

\begin{abstract}
The suitability of radioactively labeled proline as a marker of axonally transported protein in the goldfish visual system is further investigated and compared with another amino acid, leucine, in double-label experiments. Intraocularly injected proline is incorporated into protein in the eye 5 times more efficiently than is leucine, while local labeling of brain protein from precursor which has left the eye and entered the blood, (observed in the ipsilateral optic tectum) is five- to eight-fold less from proline than from leucine. The difference is attributed to the superior transport of leucine, an essential amino acid, into the brain from the blood. Once in the brain, the apparent rates of incorporation of the two amino acids are similar. Proline- or leucine-labeled, axonally transported proteins have a longer apparent half-life in the brain than do proteins labeled from intracranial injection of the precursors. By either route, proline-labeled proteins have a longer apparent half-life than leucine-labeled proteins. It is proposed that proline, released from protein breakdown is reutilized to a greater extent than is leucine.
\end{abstract}

RADIOACTIVE amino acids have previously been demonstrated to be useful in studying axonal flow in the visual system (TAYLOR \& WEISS, 1965). Following intraocular (IO) injection into the eye of a goldfish, labeled amino acids are incorporated into retinal ganglion cell proteins, which are then transported along the optic nerve to the contralateral optic tectum (GRAFSTEIN, 1967). Since the visual pathways are completely crossed, radioactivity in the ipsilateral optic tectum is due to labeled amino acid which has escaped from the eye, entered the brain from the blood, and has been incorporated into protein locally. To assess the amount of axonally transported protein in the contralateral tectum, an amount equal to that found in the ipsilateral tectum is subtracted (MCEWEN \& GRAFSTEIN, 1968). When leucine is used as the precursor, the ipsilateral labeling is more than 50 per cent of that seen on the contralateral side. Such

'Present address: National Institute of Child Health and Human Development, National Institutes of Health, Bethesda, MD 20014, U.S.A.

${ }^{2}$ Present address: Department of Biological Sciences, Florida State University, Tallahassee, FL 32306, U.S.A.

Abbreviations used: IO, intraocular; IC, intracranial; IP, intraperitoneal; COT, contralateral tectum; IOT, ipsilateral tectum; HD, half-distance. "background" incorporation is only 2-4 per cent of the total contralateral radioactivity when labeled proline is used as the precursor (ELAM \& AGRANOFF, 1971a,b; ElAM et al., 1971). Proline effectively labels 'rapidly transported protein' which arrives in the tectum about $\mathbf{8 h}$ after injection, as well as 'slowly transported protein' which arrives 2-3 weeks later. The high ratio of contralateral to ipsilateral tectal radioactivity suggested the possible usefulness of $\left[{ }^{3} \mathrm{H}\right]$-proline for tracing retinal ganglion cell projections to the brain. We have since demonstrated the efficacy of light microscopic radioautography following IO injection of high specific activity $\left[{ }^{3} \mathrm{H}\right]$-proline for the elucidation of neuroanatomical connections in the visual system (NEALE et al., 1972). While $\left[{ }^{3} \mathrm{H}\right]$-proline has rapidly gained acceptance as a precursor for biochemical (BONDY, 1971; GRAFSTEIN, 1971; MCEWEN et al., 1971; GRAFSTEIN et al., 1972; KARLSSON \& SJÖSTRAND, 1972; GrafsteIN \& LaURENO, 1973; PAUlson \& MCCLURE, 1973) as well as for radioautographic studies (HENDRICKSON et al., 1972; CROSSLAND et al., 1973) of axonal flow, the biochemical basis for its superiority as a tracer in the visual system has remained obscure. Because of a wide range of interpretations of results obtained with $\left[{ }^{3} \mathrm{H}\right]$-proline used in studies of possible transsynaptic migration 
of proteins, development of the visual system, and neuroanatomical mapping, the long-term fate of proline-labeled protein and the possible differences between $\left[{ }^{3} \mathrm{H}\right]$-proline and $\left[{ }^{3} \mathrm{H}\right]$-leucine merit further investigation and are the basis of the present study.

\section{Fish storage and injections}

\section{METHODS}

Goldfish (Carassius auratus), $6-7 \mathrm{~cm}$ in body length and weighing 8-11 g, were obtained from Ozark Fisheries, Stoutland, Mo. Fish were maintained in 150-200 gallon tanks of aged tap water in a constant temperature room with water temperatures of $20 \pm 0.5^{\circ} \mathrm{C}$. In experiments longer than 2 days, fish were fed daily.

Radiochemicals were obtained from New England Nuclear Corp. and included: L- $\left[2,3-{ }^{3} \mathrm{H}\right]$-proline (45.7 Ci/mmol), L- $\left[3,4-^{3} \mathrm{H}\right]$-proline $(29.8 \mathrm{Ci} / \mathrm{mmol}), \mathrm{L}-[\mathrm{U}-$ $\left.{ }^{14} \mathrm{C}\right]$-proline $(0.213-0.233 \mathrm{Ci} / \mathrm{mmol})$, and $\mathrm{L}-\left[4,5-{ }^{3} \mathrm{H}\right]$-leucine (30.8-36.6 Ci/mmol). Tritiated amino acids were evaporated to dryness under nitrogen and redissolved in aqueous $0.15 \mathrm{~N} \mathrm{NaCl}$ just prior to use.

Labeled precursors in $5 \mu 1$ were injected IO into the posterior chamber of the right eye through the superior pole with a $50 \mu$ l Hamilton syringe and a $\mathbf{3 0}$ gauge needle fitted with a polyethylene sleeve to limit the penetration to $2 \mathrm{~mm}$. Intracranial (IC) injections were in $10 \mu$ l given through the skull into the cranial space with a similarly fitted syringe and needle (AGRANOFF \& KLINGER, 1964).

\section{Determination of radioactivity}

Optic tecta from rinsed brains were removed and homogenized in distilled water with a glass-to-glass homogenizer. In one experiment (Fig. 4), the radioactivity in each pool of two tecta was determined directly in Spectrafluor scintillant (Amersham/Searle) after they were dissolved in Soluene-100 (Packard). Brains were homogenized in distilled water with a motor-driven teflonto-glass homogenizer. A Brinkman Polytron was used to homogenize whole eyes and lenses.

Total radioactjvity in the optic nerve was determined by immersing two nerves directly in $1 \mathrm{ml}$ of Soluene-100 for $12 \mathrm{~h}$ prior to the addition of $10 \mathrm{ml}$ of Spectrafluor. Acid-soluble radioactivity was no longer significant in the nerves $24 \mathrm{~h}$ after injection, so that total nerve radioactivity was used as a measure of the acid-insoluble fraction.

A $200 \mu \mathrm{l}$ portion of each aqueous homogenate was applied to a Whatman No. 2 filter paper disc $(4.25 \mathrm{~cm})$, dried (BANKER \& COTMAN, 1971), and treated successively with $5 \mathrm{ml}$ each of cold $5 \%$ TCA, $5 \%$ TCA at $80^{\circ} \mathrm{C}$ for $20 \mathrm{~min}$, 95\% ethanol, and two washes with ether (MANS \& NovelLI, 1961). The dried samples were combusted in a packard Sample Oxidizer in either the single or double label mode.

Samples containing tritium were counted in Bray's solution or in $15 \mathrm{ml}$ of a toluene-based scintillation mixture containing $26 \%$ Triton X-100 (v/v), $75 \mathrm{mg}$ of 2,5-diphenyloxazole (PPO) and $1.5 \mathrm{mg}$ of 1,4 bis-2-(4methyl-5 phenoxazolyl)-benzene (POPOP). ${ }^{14} \mathrm{C}$ was counted in a solution consisting of $9 \mathrm{ml}$ of methanol, $4 \mathrm{ml}$ of ethanolamine, and $6 \mathrm{ml}$ of toluene scintillant containing $90 \mathrm{mg}$ of PPO and $6 \mathrm{mg}$ of POPOP.

Aliquots of aqueous homogenates were dissolved in $\mathrm{NaOH}$, and protein was determined spectrophotometrically (LOWRY et al., 1951).

\section{Hydrolysis of protein and separation of amino acids}

Pools of 4-5 left or right tecta were homogenized in $0.5 \mathrm{ml}$ of water. One half $\mathrm{ml}$ of $10 \%$ TCA was added, and the precipitated protein was treated sequentially with TCA, ethanol and ether, as described above. One $\mathrm{ml}$ of $6 \mathrm{~N}$ $\mathrm{HCl}$ was added to the dried protein, and the mixture was heated overnight at $110^{\circ} \mathrm{C}$ in a closed screw cap tube. The $\mathrm{HCl}$ and water were evaporated under $\mathrm{N}_{2}$, followed by addition of ethanol and reevaporation. The dried hydrolysate was dissolved in $100 \mu l$ of an aqueous solution $25 \mathrm{~mm}$ in proline, leucine, glutamic acid and hydroxyproline, and $20 \mu$ of this dissolved hydrolysate with the internal standards were applied in duplicate to strips of Whatman No. 1 paper. Amino acids were separated by descending chromatography for $15-20 \mathrm{~h}$ in $n$-butanol:acetic acid:water $(60: 15: 25)$. One strip of each pair was dipped in $0.2 \%(w / v)$ ninhydrin in acetone and heated at $80^{\circ} \mathrm{C}$ until color developed. Sequential segments of the undeveloped chromatogram were counted following conbustion in the sample oxidizer. Recovery of hydrolysate radioactivity from chromatograms was 95-105 per cent, except for the ${ }^{3} \mathrm{H}$ counts in the 9 month sample in which 84 per cent recovery was obtained.

In several experiments, sample radioactivity soluble in 5\% TCA was chromatographed using the same system. TCA was removed from a concentrate by three extractions with petroleum ether. The aqueous phase was dried under $\mathrm{N}_{2}$ and suspended in a small volume of distilled water containing carrier amino acid.

\section{Determination of TCA-soluble radioactivity from blood}

Blood was obtained by inserting a heparinized capillary tube through a small incision in the ventral surface and into the pericardial cavity. From 80 to $120 \mu \mathrm{l}$ of blood were obtained per fish. Samples from 8 to 12 fish were pooled and added to an equal volume of $10 \%$ TCA, from which the acid-soluble radioactivity was determined.

\section{High resolution radioautography}

Goldfish were injected IO with $70 \mu \mathrm{Ci}$ of ${ }^{3} \mathrm{H}$-proline. Eight months later they were perfused via the ventral aorta according to the method of ROBERTSON et al., 1963, except that heparin was injected intraperitoneally before the heart was exposed, and saline was substituted for Ringer's solution for initial perfusion. The fixative was a paraformaldehyde-glutaraldehyde mixture in $0.07 \mathrm{M}$ cacodylate buffer at pH 7.5 (SOTElo \& PalAY, 1968). After $10 \mathrm{~min}$ of perfusion under manual pressure, the nerves were dissected, immersed in fresh fixative for $45 \mathrm{~min}$, and washed in cacodylate buffer containing $10 \%$ sucrose. Tissue blocks were postfixed in a chrome osmium solution (DALTON, 1955) for $45 \mathrm{~min}$ and stained en 
bloc for $1.5 \mathrm{~h}$ in $\mathbf{0 . 5 \%}$ uranyl acetate containing $0.54 \%$ sucrose. After dehydration, the samples were flatembedded in Epon.

Gray to silver cross sections of nerve were obtained using a Reichert OM U2 ultramicrotome and were mounted on Formvar-coated, carbon-stabilized grids. A thin layer of carbon was evaporated onto the sections (SALPETER \& BACHMANN, 1964), and the grids were attached to microscope slides. A layer (copper interference color) of Ilford $\mathrm{L}$ emulsion was applied over the section according to the method of CARO et al. (1962). After 26 days of exposure, the sections were developed in Microdol-X for $4 \mathrm{~min}$, fixed in 15\% sodium thiosulfate for $10 \mathrm{~min}$, rinsed, and stained with ethanolic uranyl acetate and lead citrate (REYNOLDS, 1963). Samples were examined in a Siemens Elmiskop I electron microscope at $80 \mathrm{kV}$ and photographed at 10,000 $\times$. Micrographs were enlarged to $30,000 \times$ for analysis of grain distribution according to the procedures of SALPETER et al. (1969). Micrographs were punctured with a grid of points, $1 \mathrm{~cm}$ apart. Grain densities were determined by dividing the number of points over a particular component into the number of grain midpoints overlying that component.

The typical axon radius was determined by the formula, $r=3.42 x$, where $x$ is the distance from the axon membrane into the axoplasm within which half of the total placebo points fall (BUDd \& SALPETER, 1969). All distances were measured in terms of half-distance (HD), which is the distance from a radioactive source within which half of the developed silver grains may be expected to fall. For gray sections and Ilford L4 emulsion, $1 \mathrm{HD}$ unit is calculated to be approximately $1350 \mathrm{~A}$. A theoretical integrated curve to describe the percentage of total grains expected to fall over and outside of a uniformly labeled circular source of 3 HD units radius was extrapolated from the curves presented by SALPETER et al. (1969, Fig. 13) for sources of 2 and $4 \mathrm{HD}$ units radius. For comparison with this theoretical curve, the unit distance of each grain midpoint was measured perpendicular to the nearest axon membrane.

\section{RESULTS}

Efficacy of labeled proline as a precursor for transported protein

Within hours after injection of $\left[{ }^{3} \mathrm{H}\right]$-proline or $\left[{ }^{3} \mathrm{H}\right]$-leucine into the goldfish eye, rapidly transported protein arrived in the contralateral optic tectum (COT), while the local incorporation of systemically supplied labeled amino acids was reflected by the radioactivity in the ipsilateral optic tectum (Table 1). The amount of axonally transported labeled protein was calculated from the COT-IOT difference. Proline was five-fold more efficiently incorporated into transported protein than was a similar amount of leucine. This indicated more efficient incorporation of proline into the ganglion cell protein, as is suggested by the labeling of the total eye proteins. In contrast, $\left[{ }^{3} \mathrm{H}\right]$-leucine was more effectively incorporated locally into the remainder of the brain following $\mathrm{IO}$ injection.

In order to further define the factors producing the contrasting results between the two amino acids, a time course of arrive of $\left[{ }^{3} \mathrm{H}\right]$-proline- and $\left[{ }^{3} \mathrm{H}\right]$-leucine-labeled protein in the COT was obtained for periods from $15 \mathrm{~min}$ to $16 \mathrm{~h}$ after IO injection (Fig. 1A). The TCA-soluble radioactivity of the tecta (Fig. 1B) and of the blood (Fig. 1C) was also determined. Rapidly transported labeled protein arrived in the COT between 2 and $5 \mathrm{~h}$ after the injection of each amino acid (Fig. 1A). Sixteen h following $\left[{ }^{3} \mathrm{H}\right]$-leucine injection, 53 per cent of the contralateral radioactivity could be attributed to local labeling, while this value was only 1.6 per cent with $\left[{ }^{3} \mathrm{H}\right]$-proline. The higher 'background' labeling with leucine appeared to be explained by the finding that there was 6.5 times more $\left[{ }^{3} \mathrm{H}\right]$-leucine than $\left[{ }^{3} \mathrm{H}\right]$-proline in the acid-soluble fraction of the COT $1 \mathrm{~h}$ after their respective 10 injections, despite the presence of similar amounts of the two labeled amino acids in the blood (Fig. 1C). With $\left[{ }^{3} \mathrm{H}\right]-$ proline as precursor, more soluble radioactivity was apparent in the COT than in the IOT beginning 2-5 $\mathrm{h}$ after injection, while no consistent difference was detected between the COT and IOT soluble radioactivity with $\left[{ }^{3} \mathrm{H}\right]$-leucine.

To determine the effect of the specific activity of IO-injected $\left[{ }^{3} \mathrm{H}\right]$-proline on its incorporation into transported protein, 24 fish were each injected with $\left[{ }^{3} \mathrm{H}\right]$-proline, $4.8 \mu \mathrm{Ci}, 29.8 \mathrm{Ci} / \mathrm{mmol}$, or diluted to a final specific activity of $0.298 \mathrm{Ci} / \mathrm{mmol}$. The proline at higher specific activity was 2.8 times more efficient in labeling rapidly transported protein, while no singificant difference could be detected between the two dosages in incorporation into the IOT.

\section{Turnover of transported labeled protein}

The arrival and long-term turnover of axonally transported protein at $20 \pm 0.5^{\circ} \mathrm{C}$ in the goldfish optic tectum following IO injection of both $\left[{ }^{14} \mathrm{C}\right]$-proline and $\left[{ }^{3} \mathrm{H}\right]$-leucine is presented in Fig. 2. While the pattern of arrival of slowly transported labeled protein was similar for the two isotopes, the $\left[{ }^{14} \mathrm{C}\right]$-proline-labeled protein had an apparent halflife of 103 days, while the half-life for [ $\left.{ }^{3} \mathrm{H}\right]$-leucinelabeled protein was 67 days when measured over the interval between 63 and 228 days after injection.

Chromatographic separation of amino acids following hydrolysis of tectal protein was used to 


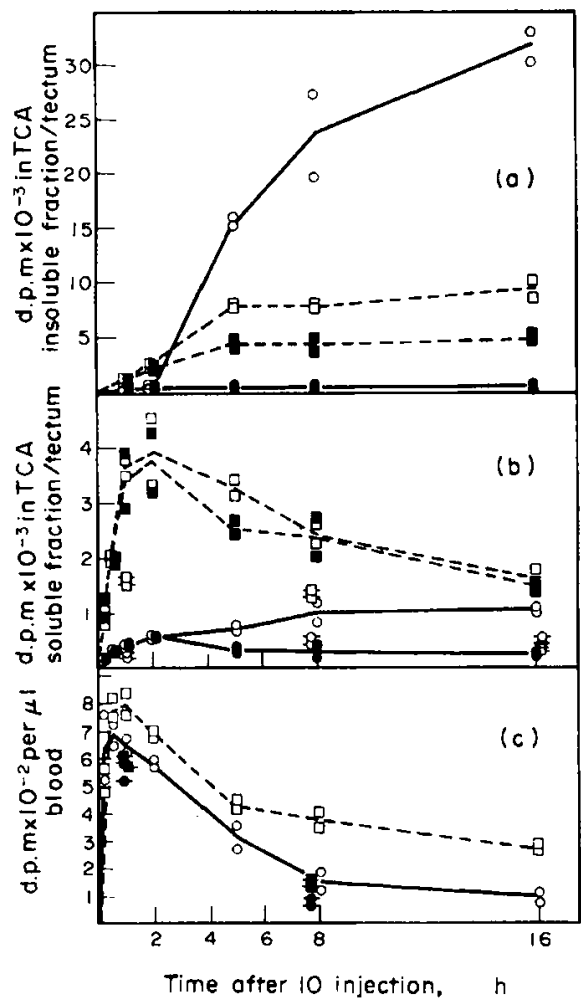

FIG. 1. (A) Acid-insoluble radioactivity in the COT after 10 injections of ${ }^{3} \mathrm{H}$-proline $(\mathrm{O}-\mathrm{O} ; 8 \mu \mathrm{Ci} ; 29.8 \mathrm{Ci} / \mathrm{mmol})$ or [ $\left.{ }^{3} \mathrm{H}\right]$-leucine $\left.(\square--\square) ; 8 \mu \mathrm{Ci} ; 30.8 \mathrm{Ci} / \mathrm{mmol}\right)$ was determined in 2 pools of 8 fish at various intervals after injection. Background incorporation in the IOT after $\left[{ }^{3} \mathrm{H}\right]$-proline ( $\left.-\infty\right)$ or $\left[{ }^{3} \mathrm{H}\right]$-leucine $(\square--\square)$ is also shown. The acid-soluble radioactivity in the optic tecta and blood from this experiment are presented in (B) and C). (B) The acid-soluble radioactivity in the COT after 10 injection of $\left[{ }^{3} \mathrm{H}\right]$-proline $(\mathrm{O}-\mathrm{O})$ or $\left[{ }^{3} \mathrm{H}\right]$-leucine $(\square---O)$, and in the IOT after IO $\left[{ }^{3} \mathrm{H}\right]$-proline ( $\left.-\infty\right)$ or $\left[{ }^{3} \mathrm{H}\right]$-leucine ( $\left.--\square\right)$ was determined in pools of 8 tecta. The amounts of $\left[{ }^{3} \mathrm{H}\right]$-proline $\left(-\mathrm{O}_{-}\right)$and $\left[{ }^{3} \mathrm{H}\right]$-leucine $(-\square-)$ in the acid-soluble fraction of the COT are shown at $1 \mathrm{~h}, 8 \mathrm{~h}$ and $16 \mathrm{~h}$ after injection. (C) The acid-soluble radioactivity was determined in pools of blood from 8 fish $\left(80-120 \mu \mathrm{l} /\right.$ fish) following IO injection of $\left[{ }^{3} \mathrm{H}\right]$-proline $(\mathrm{O}-\mathrm{O})$ or $\left[{ }^{3} \mathrm{H}\right]$-leucine $(\square-\square)$. The amounts of chromatographically isolated ${ }^{3} \mathrm{H}$-proline $(--)$ or $\left[{ }^{3} \mathrm{H}\right]-$ leucine (--) in the acid-soluble fraction of the blood are shown at $1 \mathrm{~h}$ and $8 \mathrm{~h}$ after injection.

establish what portion of the ${ }^{3} \mathrm{H}$ and ${ }^{14} \mathrm{C}$ protein radioactivity remained as leucine and proline 17 days after IO injection. From 94 to 98 per cent of the ${ }^{14} \mathrm{C}$ in the hydrolysate chromatographed with carrier proline and $90-95$ per cent of the ${ }^{3} \mathrm{H}$

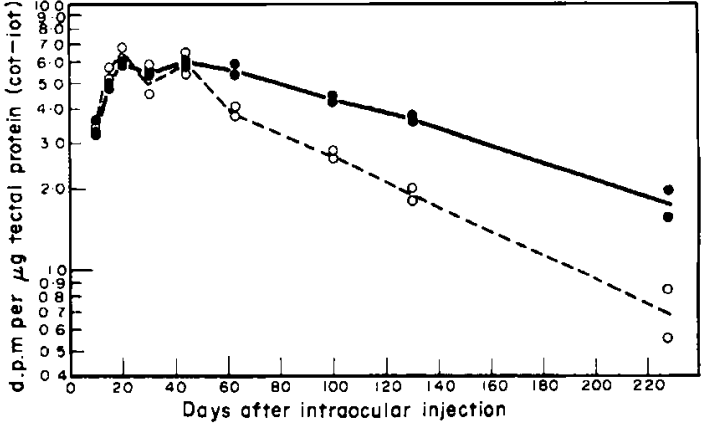

FIG. 2. Long-term turnover of axonally transported labeled protein. Fish were injected in the right eye with $0.40 \mu \mathrm{Ci}(1.9 \mathrm{nmol})\left[{ }^{14} \mathrm{C}\right]$-proline $\left(\mathrm{C}_{-}\right)$and $3.5 \mu \mathrm{Ci}$ $(0.096 \mathrm{nmol})\left[{ }^{3} \mathrm{H}\right]$-leucine $(\mathrm{O}---\mathrm{O})$ in $5 \mu \mathrm{l}$. The left and right optic tecta were removed at the indicated time intervals. Pools of 8 tecta were homogenized and the ${ }^{3} \mathrm{H}$ and ${ }^{14} \mathrm{C}$ content of the TCA-insoluble fractions were determined. The specific radioactivity (d.p.m./ $\mu \mathrm{g}$ protein) of the left tectal pools was corrected for local labeling by subtracting the activity in the right side. For example, 20 days after injection, means of $1251\left({ }^{3} \mathrm{H}\right)$ d.p.m. and $29\left({ }^{14} \mathrm{C}\right)$ d.p.m. were found per right tectum, while $3939\left({ }^{3} \mathrm{H}\right)$ and $2197\left({ }^{14} \mathrm{C}\right)$ d.p.m. were found per left tectum. The specific radioactivities determined 20 days after injection in the two right (IOT) tectal pools were 4.71 and 3.98 d.p.m. $/ \mu \mathrm{g}$ for tritium and 0.11 and 0.09 for ${ }^{14} \mathrm{C}$. In the left tectal pools, these values were 11.03 and 10.73 for ${ }^{3} \mathrm{H}$ and 6.16 and 5.96 for ${ }^{14} \mathrm{C}$.

comigrated with leucine in fish injected with both labeled amino acids. Similar results were obtained in hydrolysates of protein from animals killed nine months after injection.

In another experiment, the turnover of $\left[{ }^{3} \mathrm{H}\right]$ proline-labeled transported protein was determined between 61 and 377 days after 10 injection, and a half-life of 135 days was observed when fish were maintained at $18-19^{\circ} \mathrm{C}$.

Since apparent differences in turnover of prolineand leucine-labeled transported protein may result from differential protein turnover in the eye, coupled with continuous supply via axonal flow of small amounts of proline-labeled protein, the total radioactivity in protein of the lens and the remainder of the eye was determined in the same group of fish. The optic tectum turnover of this group is presented in Fig. 2. During the first 30 days after injection, $\left[{ }^{3} \mathrm{H}\right]$-leucine-labeled protein appeared to be somewhat more rapidly degraded than $\left.{ }^{14} \mathrm{C}\right]$-proline-labeled protein in the eye (Fig. 3). There was, however, no significant difference between ${ }^{3} \mathrm{H}$ and ${ }^{14} \mathrm{C}$ loss in protein thereafter. While the lens incorporated substantial amounts of both 


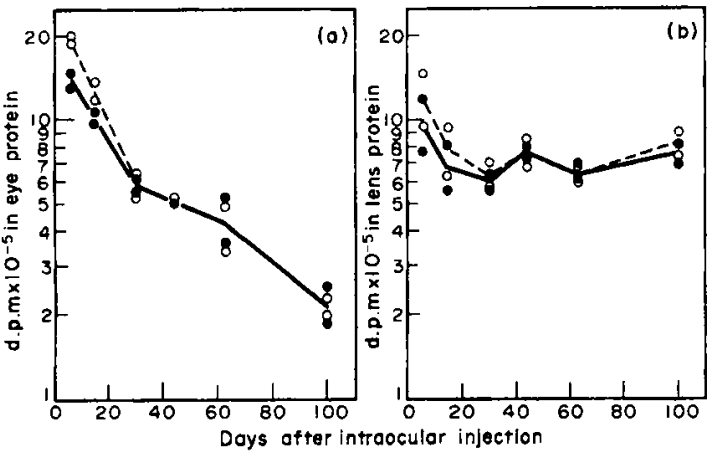

FIG. 3. TCA-insoluble radioactivity in the lens and in the remainder of the eye following IO injection of $0.40 \mu \mathrm{Ci}$ $\left[{ }^{14} \mathrm{C}\right]$-proline and $3.5 \mu \mathrm{Ci}\left[{ }^{3} \mathrm{H}\right]$-leucine (Fig. 2). The acid-insoluble $\left[{ }^{14} \mathrm{C}\right]$-proline $(\mathrm{O}$ (O---O) were determined in pools of 8 eyes (A) with lenses removed and pools of 8 lenses $(B)$.

labeled amino acids, significant turnover of this protein was not observed.

\section{Radioactivity in the optic nerve}

As can be seen in Fig. 4, slowly transported labeled protein arrived in the optic tectum after it appeared in the optic nerve. In contrast to the decline in radioactivity in the nerve after rapidly transported protein passed through it (ELAM \& AGRANOFF, 1971a), the nerve became heavily labeled with slowly transported protein, and its radioactivity persisted and paralleled that of the COT, declining only after many weeks.

Since considerably more labeled protein is believed transported by slow axonal flow than by rapid flow (MCEWEN \& GRAFSTEIN, 1968; ELAM \& AGRANOFF, 1971b), and much of the slowly transported protein may remain in the retinal ganglion cell axon present in the tectum, the apparent half-lives observed in Fig. 2 may reflect a significant contribution from the axon or from its surrounding myelin sheath. High resolution radioautography of the optic nerve was performed to evaluate the contribution of myelin to the radioactivity in the optic nerve 8 months after IO injection of $\left[{ }^{3} \mathrm{H}\right]$-proline (Fig. 5). In the ultrathin sections analyzed, axoplasm occupied 1.4 times the area of myelin and contained 3.3 times the number of exposed silver grains; hence it possesses 2.3 times the grain density of the myelin. The average axon radius was 3 half distance (HD) units. For a uniformly labeled circular source of this radius, 52 per cent of the total grains should lie over the source, while 45 per cent should fall within $8 \mathrm{HD}$

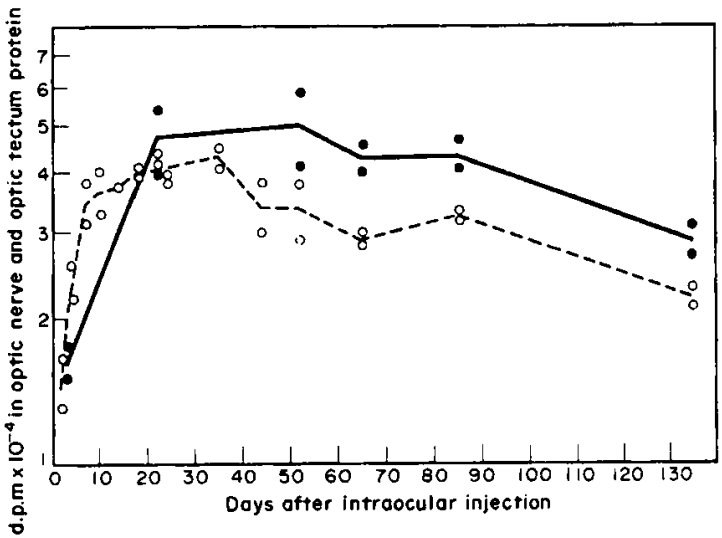

FIG. 4. Axonal transport of labeled protein in the goldfish optic nerve of the injected eye and its optic tectum. Fish were injected IO with $5 \mu \mathrm{Ci}$ of $\left[{ }^{3} \mathrm{H}\right]$-proline and the total precipitable radioactivities in the optic nerve $(\mathrm{O}--\mathrm{O})$ between the eye and chiasm and in the optic tectum $(\mathrm{O}-\mathrm{O}$ ) were determined. Each point represents the total d.p.m. per pool of two fish.

units outside of the source as a result of scatter from the source (SALPETER et al., 1969). In this study, 60 per cent of the total grains were found over the axoplasm, and 35 per cent were found up to $8 \mathrm{HD}$ units outside the axolemma. The myelin sheath occupied up to $1.5 \mathrm{HD}$ units outside the axolemma and accounted for 25 - per cent of the grains. This distribution is to be expected as a result of scatter from the source, and it may be concluded that extra-axonal compartments, including myelin did not contain substantial amounts of $\left[{ }^{3} \mathrm{H}\right]$-prolinelabeled protein and that the axoplasm is the site of the radioactivity in the nerve.

\section{Incorporation and turnover after intracranial injec -} tion

When equal amounts of $\left[{ }^{3} \mathrm{H}\right]$-proline or $\left[{ }^{3} \mathrm{H}\right]-$ leucine of similar specific activity were injected intracranially (IC), the acid-soluble radioactivity decreased more quickly with leucine than with proline (Table 2). The two radioactivities approached similar levels by $8 \mathrm{~h}$. During this interval, much more labeled proline than leucine was incorporated into brain protein although the relative rates of incorporation of the two amino acids from their respective labeled pools appeared similar, as reflected by the ratio of precipitable to soluble radioactivity at early times. The difference in amounts of the acid-soluble labeled amino acids remaining would appear to account for the differences in incorporation. Via the intracranial route, 
TABLE 1. SPECIFIC RADIOACTIVITY IN THE PROTEIN OF THE OPTIM TECTUM 48 h AFTER IO INJECTION OF ${ }^{3}$ H-PROLINE OR ${ }^{3}$ H-LEUCINE*

\begin{tabular}{|c|c|c|c|}
\hline \multicolumn{4}{|c|}{ Specific activity of tectal nrntein (d.p.m./ $\mathrm{gg}$ ) } \\
\hline \multicolumn{2}{|c|}{ From ${ }^{3} \mathrm{H}$-proline } & \multicolumn{2}{|c|}{ From ${ }^{3} \mathrm{H}$-leucine } \\
\hline $\begin{array}{l}\text { Contralateral } \\
\text { tectum (COT) }\end{array}$ & $\begin{array}{c}\text { Ipsilateral } \\
\text { tectum (IOT) }\end{array}$ & $\begin{array}{l}\text { Contralateral } \\
\text { tectum (COT) }\end{array}$ & $\begin{array}{l}\text { Ipsilateral } \\
\text { tectum (IOT) }\end{array}$ \\
\hline $55 \cdot 77$ & $1 \cdot 35$ & 21.69 & $12 \cdot 21$ \\
\hline 70.06 & 1.25 & $22 \cdot 15$ & $12 \cdot 25$ \\
\hline $74 \cdot 89$ & 1.25 & 26.03 & $10 \cdot 63$ \\
\hline & ${ }^{3} \mathrm{H}$-proline & ${ }^{3} \mathrm{H}$-leucine \\
\hline & Mean COT minus IOT & 65.62 & 11.59 \\
\hline \multicolumn{2}{|c|}{ Mean COT/IOT } & $52 \cdot 14$ & 1.99 \\
\hline \multirow{2}{*}{\multicolumn{2}{|c|}{$\begin{array}{l}\text { \% Injected dose incorporated: } \\
\text { (a) into rapidly transported protein } \\
\text { (b) into total eye protein }\end{array}$}} & & $0.020 \%$ \\
\hline & & $\begin{array}{l}0.115 \% \\
32.8 \%\end{array}$ & $7.8 \%$ \\
\hline \multicolumn{2}{|c|}{ ratio of $\mathrm{a} / \mathrm{b}$} & 0.0035 & 0.0026 \\
\hline
\end{tabular}

*In three separate experiments, the specific activity was determined in pools of 8 optic tecta $48 \mathrm{~h}$ after $\mathrm{IO}$ injection of $9.5 \mu \mathrm{Ci}$ of $\left.{ }^{3} \mathrm{H}\right]$-proline $(29.8 \mathrm{Ci} / \mathrm{mmol})$ or $\left[{ }^{3} \mathrm{H}\right]$-leucine $(30.8 \mathrm{Ci} / \mathrm{mmol})$. Total acid-insoluble radioactivity was determined in pools of 8 eyes (including lenses) and expressed as a per cent of the injected dose.

TABLE 2. InCORPORATION OF ${ }^{3} \mathrm{H}$-PROLINE AND ${ }^{3} \mathrm{H}$-LEUCINE AFTER IC INJECTION*

\begin{tabular}{cccc}
\hline & $\begin{array}{c}\text { Acid- } \\
\text { insoluble } \\
\text { Incorporation } \\
\text { interval }\end{array}$ & $\begin{array}{c}\text { Acid- } \\
\text { soluble } \\
\text { (S) }\end{array}$ & \\
\hline${ }^{3}$ H-Proline & & & \\
4 min & 10.71 & 253.9 & 0.042 \\
per brain & I/S \\
\hline min & 35.44 & 255.3 & 0.139 \\
h & 166.3 & 317.2 & 0.524 \\
4 h & 250.7 & 93.1 & 2.69 \\
$8 \mathrm{~h}$ & 325.9 & 26.99 & 12.07 \\
& & & \\
${ }^{3}$ H-Leucine & & & \\
4 min & 11.52 & 247.5 & 0.047 \\
9 min & 25.99 & 192.1 & 0.135 \\
I h & 45.31 & 89.15 & 0.508 \\
8 h & 79.17 & 27.6 & 2.91 \\
\hline
\end{tabular}

*The acid-soluble and insoluble radioactivity was determined in pools of 15 brains at various times after IC injection of $2 \cdot 2 \mu \mathrm{Ci}$ of $\left[{ }^{3} \mathrm{H}\right]$-proline $(29.8 \mathrm{Ci} / \mathrm{mmol})$ or $\left.{ }^{3} \mathrm{H}\right]$-leucine $(30 \cdot 8 \mathrm{Ci} / \mathrm{mmol})$.

there appeared to be no bar to proline incorporation into the brain.

To determine whether the apparent difference in half-life between proline- and leucine-labeled protein was peculiar to transported protein, goldfish were injected IC with a mixture of $\left[{ }^{14} \mathrm{C}\right]$-proline and $\left[{ }^{3} \mathrm{H}\right]$-leucine (Fig. 6). The half-lives for doublelabeled proteins, calculated between 27 and 71 days after IC injection, were 82 days for proline-labeled protein and 45 days for leucine-labeled protein.
Incorporation in the brain after IO and IP injection

Thirty minutes after intraperitoneal (IP) injection of similar amounts of $\left[{ }^{3} \mathrm{H}\right]$-proline or $\left[{ }^{3} \mathrm{H}\right]$-leucine, there was 25 per cent more soluble radioactivity in the blood from leucine than from proline (Table 3 ). There was, however, 3-fold more soluble radioactivity in the brain from $\left[{ }^{3} \mathrm{H}\right]$-leucine, and this was reflected in the amount of labeled protein formed. In the kidney, there were equal amounts of acid-insoluble and soluble ${ }^{3} \mathrm{H}$ after IP injection of either amino acid, and the ratio of insoluble to soluble radioactivity indicated that the two precursors were being incorporated similarly.

One hour after IO injection of $\left[{ }^{3} \mathrm{H}\right]$-proline or $\left[{ }^{3} \mathrm{H}\right]$-leucine, the optic tecta were excised. They should be labeled only by radioactivity which has escaped from the eye and entered from the blood, since axonally transported protein has not yet arrived (Table 4). The labeling pattern was similar to that observed in the blood and brain following IP injection. There was slightly more soluble radioactivity in the blood from the IO leucine injection than from proline, but considerably more radioactivity entered the acid-soluble fraction of the tectum when leucine was the precursor. The relative degree of incorporation measured by the ratio of acid-insoluble to soluble radioactivity was similar for the two amino acids in both the tectum and kidney, following IO injection.

\section{DISCUSSION}

The effectiveness of labeled proline as a precursor of transported protein in the fish visual system 


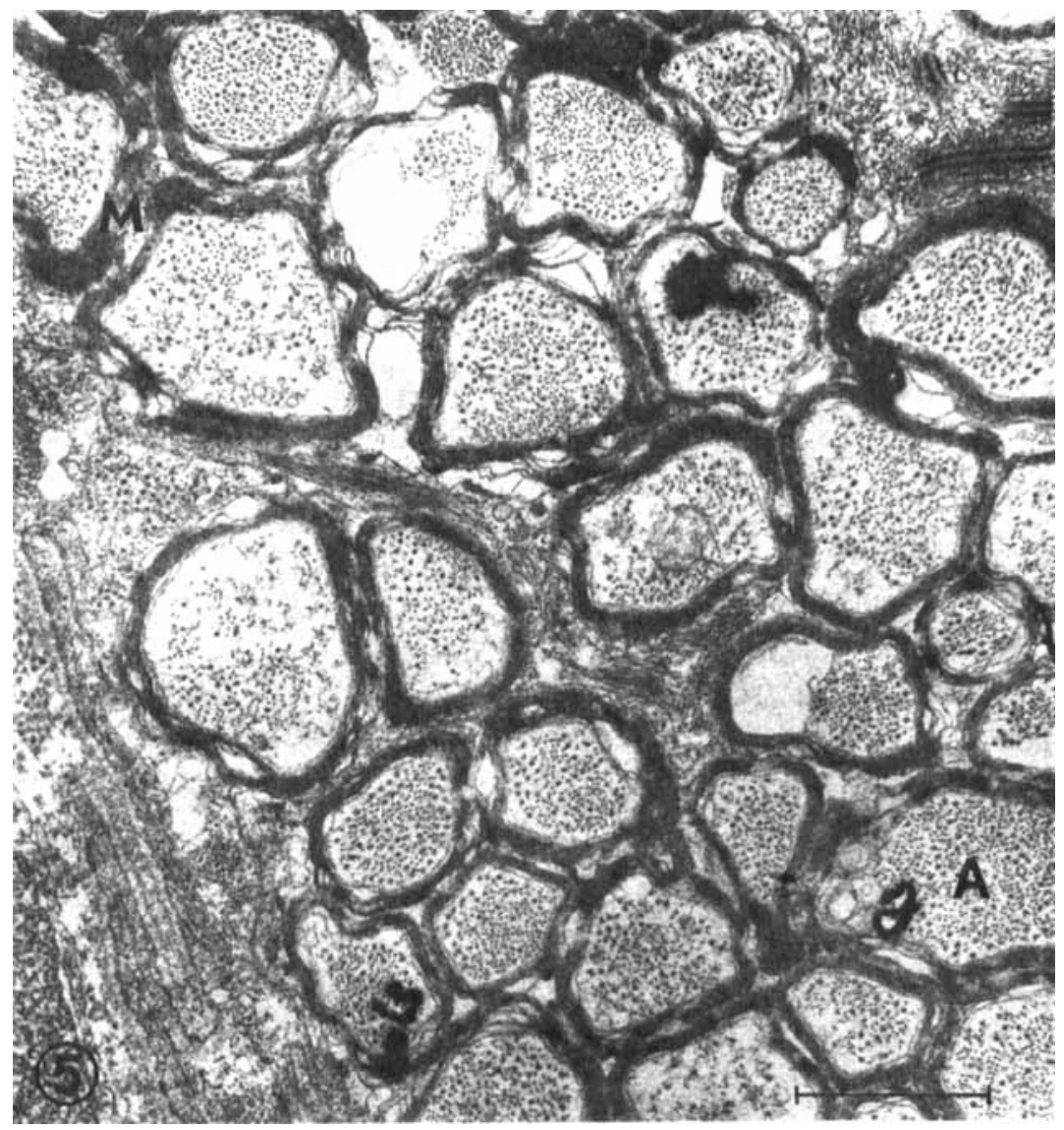

Fig. 5. High resolution radioautogram of goldfish optic nerve 8 months after 10 injections with $\left[{ }^{3} \mathrm{H}\right]$ proline (see text). Developed silver grains are seen over axoplasm (A) and also over myelin (M). Analysis of more than $\mathbf{2 0 0}$ grains indicated that those grains outside axoplasm are a result of scatter from a radioactive source the size of a typical axon. Magnification bar $=1 \mu \mathrm{m} . \times 20,000$. 
TABLE 3. INCORPORATION OF ${ }^{3} \mathrm{H}$-PROLINE AND ${ }^{3} \mathrm{H}$-LEUCINE INTO BRAIN AND KIDNEY PROTEIN AFTER INTRAPERITONEAL INJECTION*

\begin{tabular}{|c|c|c|c|c|c|c|}
\hline \multirow{2}{*}{$\begin{array}{l}\text { Blood } \\
\text { Acid } \\
\text { soluble }\end{array}$} & \multicolumn{3}{|c|}{ Brain } & \multicolumn{3}{|c|}{ Kidney } \\
\hline & $\begin{array}{c}\text { Acid } \\
\text { insoluble (I) }\end{array}$ & $\begin{array}{c}\text { Acid } \\
\text { soluble (S) } \\
\left.\text { (d.p.m. } \times 10^{-3}\right)\end{array}$ & $\mathrm{I} / \mathrm{S}$ & $\begin{array}{c}\text { Acid } \\
\text { insoluble (I) }\end{array}$ & $\begin{array}{c}\text { Acid } \\
\text { soluble }(\mathbf{S}) \\
\left.\text { (d.p.m. } \times 10^{-3}\right)\end{array}$ & I/S \\
\hline $\begin{array}{c}{ }^{3} \mathrm{H}-\text { Proline } \\
4 \cdot 18 \\
( \pm 0 \cdot 64) \\
{ }^{3} \mathrm{H}-\text {-Leucine }\end{array}$ & $\begin{array}{c}2.96 \\
( \pm 0.18)\end{array}$ & $\begin{array}{c}31.4 \\
( \pm 1.3)\end{array}$ & $\begin{array}{c}0.094 \\
( \pm 0.005)\end{array}$ & $\begin{array}{c}111 \\
( \pm 17)\end{array}$ & $\begin{array}{c}498 \\
( \pm 53)\end{array}$ & $\begin{array}{c}0.225 \\
( \pm 0.053)\end{array}$ \\
\hline $\begin{array}{c}5.24 \\
( \pm 0.62)\end{array}$ & $\begin{array}{c}13.4 \\
( \pm 0.9)\end{array}$ & $\begin{array}{c}96 \cdot 3 \\
( \pm 2 \cdot 9)\end{array}$ & $\begin{array}{c}0.138 \\
( \pm 0.007)\end{array}$ & $\begin{array}{c}110 \\
( \pm 14)\end{array}$ & $\begin{array}{c}438 \\
( \pm 20)\end{array}$ & $\begin{array}{c}0.254 \\
( \pm 0.022)\end{array}$ \\
\hline
\end{tabular}

*The mean ( \pm S.D.) incorporation per organ is presented for 3 pools of 12 fish 30 min after IP injection of $12 \cdot 3 \mu \mathrm{Ci}$ of $\mathrm{L}\left[2,3-{ }^{3} \mathrm{H}\right]$-proline $(41 \cdot 4 \mathrm{Ci} / \mathrm{mmol})$ or $L\left[4,5-{ }^{3} \mathrm{H}\right]$-leucine $(35 \cdot 5 \mathrm{Ci} / \mathrm{mmol})$. Chromatography of blood acid-soluble radioactivity indicated that at $30 \mathrm{~min}, 88$ per cent of the radioactivity after IP ${ }^{3} \mathrm{H}$-proline was in proline and that 82 per cent of the radioactivity after IP $\left[{ }^{3} \mathrm{H}\right]$-leucine was in leucine. Blood acid-insoluble fraction was not measured.

TABLE 4. INCORPORATION OF ${ }^{3}$ H-PROLINE AND ${ }^{3} \mathrm{H}$-LEUCINE INTO TECTUM AND KIDNEY PROTEIN AFTER INTRAOCULAR INJECTION*

\begin{tabular}{|c|c|c|c|c|c|c|c|}
\hline \multicolumn{2}{|c|}{ Blood } & \multicolumn{3}{|c|}{ Tectum } & \multicolumn{3}{|c|}{ Kidney } \\
\hline $\begin{array}{r}\text { Aci } \\
30 \mathrm{~min} \\
\text { (d.p }\end{array}$ & $\begin{array}{l}\text { ble } \\
60 \mathrm{~min}\end{array}$ & $\begin{array}{c}\text { Acid } \\
\text { insoluble } \\
\text { (I) }\end{array}$ & $\begin{array}{c}\text { Acid } \\
\text { soluble } \\
(\mathbf{S}) \\
\text { (total d.p.m.) }\end{array}$ & $\mathrm{I} / \mathrm{S}$ & $\begin{array}{c}\text { Acid } \\
\text { insoluble } \\
\text { (I) }\end{array}$ & $\begin{array}{c}\text { Acid } \\
\text { soluble } \\
\text { (S) } \\
\text { (total d.p.m.) }\end{array}$ & I/S \\
\hline \multicolumn{8}{|c|}{${ }^{3}$ H-Proline } \\
\hline 736 & 673 & 147 & 456 & 0.322 & 9701 & 58650 & 0.165 \\
\hline 648 & 627 & 110 & 368 & 0.298 & 10080 & 61200 & 0.164 \\
\hline \multicolumn{8}{|c|}{${ }^{3} \mathrm{H}$-Leucine } \\
\hline 744 & 761 & 940 & 3814 & 0.246 & 10210 & 55740 & 0.183 \\
\hline 814 & 833 & 928 & 3249 & 0.285 & 12620 & 68200 & 0.185 \\
\hline
\end{tabular}

* Radioactivity in acid-soluble and acid-insoluble fractions expressed per organ was determined in pools of 8 goldfish following $\mathrm{IO}$ injection of $8 \mu \mathrm{Ci}$ of $\left[{ }^{3} \mathrm{H}\right]$-proline $(29.8 \mathrm{Ci} / \mathrm{mmol})$ or ${ }^{3} \mathrm{H}$-leucine $(30.8 \mathrm{Ci} / \mathrm{mmol})$. The data are from the experiment presented in Fig. 1. The tectal data are mean values obtained from determinations of the pooled contralateral and ipsilateral optic tecta. The appearance of radioactivity in the kidney was measured at $30 \mathrm{~min}$; tectal radioactivity was measured in a separate experiment at $60 \mathrm{~min}$, since there was insufficient labeling $30 \mathrm{~min}$ after injection.

can be attributed both to its efficient incorporation into retinal ganglion cell protein and to its relatively inefficient movement from the blood into the brain. The basis for its high rate of incorporation into protein in the eye may lie in part of the small size of the proline pool in the vitreous humor or in the retina itself, in a rapid rate of transport of proline into the retinal ganglion cell, or in its slow rate of disappearance via transport or metabolism relative to other amino acid precursors. In the carp retina, the reported total free leucine pool is one-third greater than that of proline, while in the vitreous humor, proline is not measurable (CSANYI et al., 1973). The decrease in labeling of transported protein that resulted when the specific activity of added $\left[{ }^{3} \mathrm{H}\right]$-proline was lowered suggests a signifi- cant role for the precursor pool size in labeling of transported protein. From the dilution study, we calculated that an endogenous pool in the eye of approximately $9 \mathrm{nmol}$ of proline equilibrated with the injected precursor.

In the initial study which reported efficaciousness of proline for axonal flow studies in the visual system (ELAM \& AGRANOFF, 1971 $a$ ), 18 amino acid precursors were compared. The 11 amino acids ordinarily considered essential in the fish (including cysteine; PHILlIPS, 1969) yielded COT/IOT ratios of labeled proteins of less than 3, while the non-essential amino acids had higher ratios. An exception was glutamic acid which was poorly incorporated into transported protein, probably because of its high concentration in tissues. In the 


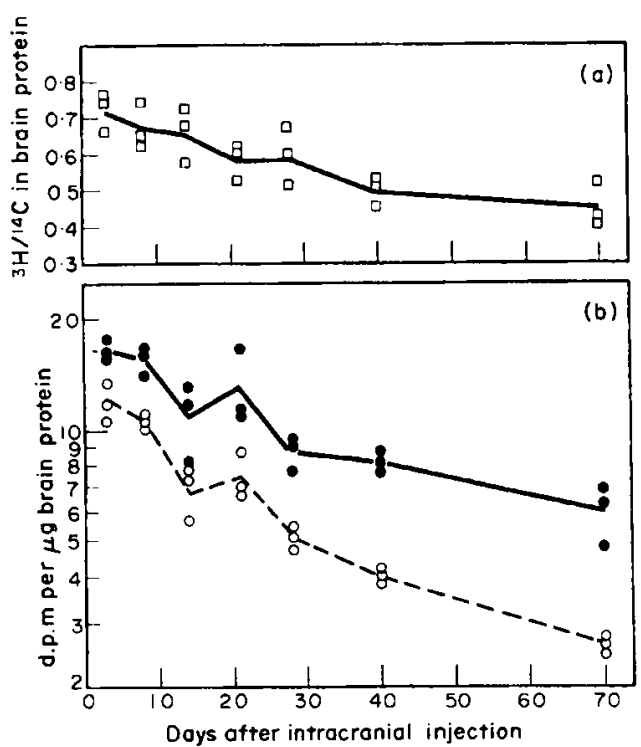

FIG. 6. Specific radioactivity in fish brain protein following IC injection of $0.64 \mu \mathrm{Ci}$ of ${ }^{14} \mathrm{C}$-proline and $1.33 \mu \mathrm{Ci}$ of $\left[{ }^{3} \mathrm{H}\right]$-leucine. The ratio of ${ }^{3} \mathrm{H}$ to ${ }^{14} \mathrm{C}$ in brain protein is shown in $\mathrm{A}$. The TCA insoluble radioactivity as $\left[{ }^{14} \mathrm{C}\right]-$ proline $(-)$ and $\left[{ }^{3} \mathrm{H}\right]$-leucine $(\mathrm{O}--\mathrm{O})$ was determined for pools of 12 fish at the indicated time intervals (B). These data represent the pools of brains homogenized after optic tecta were removed and separately assayed. The tecta generally contained approximately 10 per cent of the protein and radioactivity in whole brain but had greater variability.

present report, we note that the essential amino acid, leucine, enters the brain from blood more effectively than does a non-essential amino acid, proline. The other essential amino acids may similarly be poor precursors for studying axonal transport in the visual system, that is because they are readily transported into the brain from the blood and result in relatively high incorporation. Leucine and other essential amino acids (tyrosine is considered an essential amino acid for the brain) are reported to enter the brain rapidly while proline and other non-essential amino acids enter more slowly (OLDENDORF, 1971; YUDILEVICH et al., 1972). Of interest, some proline esters enter the brain more effectively than does the natural amino acid (DINGMAN \& SPORN, 1959). Dilution of precursors with unlabeled amino acids in the blood should also affect their rate of entry. Twice as much proline as leucine has been reported in carp blood (CREACH \& Serafaty, 1964). A barrier to proline may exist within the brain. KUNZLE \& CUENOD (1973) have recently reported radioautographic evidence that $\left[{ }^{3} \mathrm{H}\right]$-proline is taken up much less effectively than is $\left[{ }^{3} \mathrm{H}\right]$-leucine in the cat lateral reticular nucleus. By contrast, small neighboring cells (neurons or glia) are preferentially labeled by proline. The result is confounded by the fact that the two isotopes were injected intracerebrally in significantly different amounts and specific activities. In the case of the visual system, there is no evidence that different cell types are involved in any of the differences seen in incorporation or turnover. The result points out, however, a possible complexity in the use of amino acid incorporation into protein as a means of tracing neuronal pathways.

The high level of acid-soluble radioactivity found in the brain after 10 injection of $\left[{ }^{3} \mathrm{H}\right]$-leucine is consistent with the observed high degree of in situ labeling of protein. No consistent difference was detected between the COT and IOT acid-soluble fractions. This has been interpreted to indicate that free leucine is not transported axonally (MCEWEN \& GRAFSTEIN, 1968). While the acid-soluble fractions are much less radioactive following $\left[{ }^{3} \mathrm{H}\right]-$ proline IO injection, there is more acid-soluble radioactivity in the COT than in the IOT with the latter precursor. This COT - IOT value is not likely to be due to axonal flow of free $\left[{ }^{3} \mathrm{H}\right]$-proline, since other amino acids have been shown not to be transported, and studies in the carp indicate that no significant amount of $\left[{ }^{3} \mathrm{H}\right]$-proline passes through the distal portion of the optic tract after its IO injection (CSANYI et al., 1973). The increased COT acid-soluble radioactive proline could result from breakdown of labeled transported protein. The presence of acid-soluble radioactivity with a time course that parallels that of the labeled transported protein in the COT is consistent with this interpretation. If the acid-soluble radioactivity resulted from breakdown of labeled transported protein, a similar release of acid-soluble material from ${ }^{3} \mathrm{H}$ leucine labeled protein might have occurred but not have been detected. In the experiments with labeled proline, the COT-IOT acid-soluble radioactivity examined at various times after injection, was $2-3$ per cent of the rapidly labeled protein. This amounted to several times the total IOT acid-soluble radioactivity and was thus readily measured. However, in the analogous experiments with labeled leucine, if we assume there is also a 2-3 per cent enrichment with free leucine in the COT acid-soluble fraction, we could expect only 7 per cent more radioactivity in the acid-soluble fraction of the COT than in the IOT acid-soluble radioactivity $5 \mathrm{~h}$ after injection (Fig. 1). Variation in 
experimental values thus precluded identification of such a putative increment in the COT following ${ }^{3} \mathrm{H}$-leucine injection. Since the amount of radioactivity in the acid-soluble fractions arriving via the blood is very low relative to the amounts of labeled protein a few days following the $\mathrm{IO}$ injection of $\left[{ }^{3} \mathrm{H}\right]$-leucine, it then becomes possible to examine the possibility of a COT-IOT difference. Fortyfive days following either labeled proline or leucine injection, the COT - IOT acid-soluble radioactivity is found equal to about 1 per cent of the acid-insoluble fractions in each instance. The persistence of the COT-IOT difference as a relatively fixed percentage of the acid-insoluble fraction suggested the alternate possibility that our protein precipitation method might not be complete, or that small acid-soluble peptides were transported axonally and appeared in the acidsoluble fraction. Paper chromatographic analyses of the acid-soluble fractions at various times after injection indicated, however, that the major radioactive spot in each instance comigrated with the precursor amino acid. The results are then interpreted to indicate that labeled protein breakdown is the source of a significant fraction of the acid-soluble radioactivity. This observation is discussed further below in regard to reutilization of amino acids as they may affect calculated protein half-lives.

We have documented in the present study, a significant difference in apparent half-lives of axonally transported proteins as a function of the precursor amino acid used. We find turnover of leucine-labeled transported protein to be 67 days at $20 \pm 0 \cdot 5^{\circ}$. Kinetics of protein labeled locally with $\left[{ }^{3} \mathrm{H}\right]$-leucine was studied following IC injection. In this instance, the half-life was 45 days, significantly shorter than that for transported protein. Calculation of local labeling by $\left[{ }^{3} \mathrm{H}\right]$-leucine in the IOT following IO injection gave a much longer half-life, approximately that of the COT. This is unexplained, but could be due in part to slow release of labeled leucine from highly labeled protein in the eye as discussed below. GRAFSTEIN et al. (1973) have observed a marked difference in the turnover of leucine- and proline-labeled transported protein in the mouse visual system. Proline-labeled protein showed virtually no turnover, while leucine-labeled protein decayed rapidly. In a separate study in the fish, the half-life of leucine-labeled transported protein was reported at various ambient temperatures (GRAFSTEIN et al., 1972). At $20.5^{\circ}$, the half-life of leucine-labeled transported protein (COT minus IOT) was reported to be 6 weeks, much shorter than we found, while that for locally synthesized IOT was reported to be seven weeks.

The present studies show that protein labeled following IC injection turns over much more rapidly than does axonally transported protein and this difference is seen when $\left[{ }^{3} \mathrm{H}\right]$-proline is the precursor as well. This difference in half-life as a function of route of administration of the protein precursor may reflect a number of intervening factors, among them considerations regarding the distribution of radioactivity in different brain cell populations, into subcellular fractions and within protein species, as well as other possible confounding factors inherent in measurements of total protein turnover (SCHIMKE \& DOYLE, 1970). In the case of comparison of axonally transported and locally synthesized proteins, there are additional considerations. The possibility exists that the transported labeled tectal protein is in continuous circulation with a larger amount of labeled protein present in the ganglion cell. Although we have not examined the retina by radioautography, we have found large amounts of radioactivity throughout the eye, even after several months. The measured apparent half-life may therefore be prolonged by a continued supply of protein from the retina as is suggested by the persistence of radioactivity in the optic nerve for long periods of time (Fig. 4). There is the further possibility of continuous circulation of macromolecules and organelles, such as mitochondria, between the nerve ending and its cell body. Since amino acids are incorporated almost entirely by polysomes in the perikaryon, the labeled protein demonstrates only proximodistal flow. Other techniques indicate that there may indeed be distoproximal flow, so that the two processes together may constitute a circulation. Histochemical study of the fate of peroxidase after injection into the chick optic tectum has revealed retrograde axonal flow in the retinal ganglion cell (LAVAIL \& LaVAIL, 1972). Another consideration, often neglected in in vivo studies, is that the use of first order decay kinetics may not be entirely appropriate. Transported organelles, such as mitochondria and synaptic vesicles, may, like erythrocytes, have specific lifetimes rather than half-lives. They would show little turnover until they are destroyed. The observed decay curves could result from a combination of these two or even more kinds of decay.

The difference in observed half-lives of protein when proline or leucine is the precursor was seen following both IO and IC injections. Differences in measured brain protein turnover rates as a function of different systemic precursors have previously 
been observed (LAJTHA, 1964). While considerable differences in half-lives of specific brain proteins have been reported as well (LAJTHA \& MARKS, 1971), in order for these differences to account for our results with leucine and proline, one must postulate the presence of a substantial amount of slowly turning over protein highly labeled with proline.

Differential reutilization in the brain of amino acids released from protein breakdown could explain the difference in apparent half-lives of leucine- and proline-labeled proteins. Substantial differences in apparent turnover rates of specific isolated proteins have been shown to depend upon the labeled precursors used (ARIAS et al., 1969; JOHNSON \& VELICK, 1971; POOLE, 1971; GARLICK \& MARSHALL, 1972). During initial labeling following IC injection, $\left[{ }^{3} \mathrm{H}\right]$-proline remains present in the acid-soluble fraction significantly longer than does $\left[{ }^{3} \mathrm{H}\right]$-leucine and might therefore be reutilized more effectively. Although the measured brain free amino acid pool may not reflect the pool used for protein synthesis, we did observe a four-fold greater labeling from proline than from leucine following the IC injection of labeled amino acids. It remains possible that the cell population labeled following IC injection is different with the two amino acids (KUNZLE \& CUENOD, 1973). It is less likely that this could account for the difference in the two amino acids following 10 injection. The difficulty in evaluating the relationship between the total intracellular labeled amino acid present and the rate of its incorporation or reutilization relates to questions regarding the role of the measurable intracellular amino acid pool in protein synthesis (KIPNIS et al., 1961; GRANT, 1969; HIDER et al., 1971). In vitro studies of labeled leucine incorporation into protein in pancreas slices indicate that the specific activity of the amino acid pool in the incubation medium is more relevant than that of the measured intracellular labeled amino acid (VAN VENROOIJ et al., 1972).

The high resolution radioautographic study indicates that the labeled protein is primarily axonal. Using light microscopic radioautography, we have observed the presence of silver grains over the valvula of the cerebellum following IO injection. Since this brain region is separated from the tectum by the ventricular space, and since no tectal neurons are known to project axons into this region, the result indicated that labeled protein or $\left[{ }^{3} \mathrm{H}\right]$-proline-labeled protein has left the presynaptic region and migrated to the cerebellum, followed in the latter case by reincorporation. The present results add a further note of caution in interpretation of radioautographic studies where transneuronal migration of protein is suggested (see DROZ et al., 1973).

Acknowledgments-This study was supported by grants from the National Institute of Mental Health (MH 12506) and the National Science Foundation (GB 32409X1). J. H. N. and J. S. E. were supported by Training Grant MM 07417 and E. A. N. was supported by NS 50407 .

\section{REFERENCES}

AGRANOFF B. W. \& KLINGER P. D. (1964) Science, N.Y. 146, 952-953.

ARIAS I. M., DOYLe D. \& SChimke R. T. (1969) J. biol. Chem. 244, 3303-3315.

BANKer G. \& CotMan C. W. (1971) Archs Biochem. Biophys. 142, 565-573.

Bondy S. C. (1971) Exp. Brain Res. 13, 127-134.

Budd G. C. \& Salpeter M. M. (1969) J. Cell Biol. 44, 21-32.

Caro L. G., van Tubergen R. P. \& Kolb J. A. (1962) J. Cell Biol. 15, 173-188.

Creach Y. \& Servaty A. (1964) Societe de Biologie de Toulouse 158, 1152-1156.

Crossland W. J., Cowan W. M. \& Kelly J. P. (1973) Brain Res. 56, 77-105.

CSANYi V., Gervai J. \& Lajtha A. (1973) Brain Res. 56, 271-284.

Dalton A. J. (1955) Anat. Rec. 121, 281.

Dingman W. \& SPORN M. B. (1959) J. Neurochem. 4, 148-153.

Droz B., Koenig H. L. \& Di Giamberardino L. (1973) Brain Res. 60, 93-121.

Elam J. S. \& AGranoff B. W. (1971a) J. Neurochem. 18, 375-387.

Elam J. S. \& Agranoff B. W. (1971b) J. Neurobiol. 2 , 379-390.

Elam J. S., Neale E. A. \& Agranoff B. W. (1971) Acta Neuropath. (Berl.) Suppl. V, 257-266.

Garlick P. J. \& MarShall I. (1972) J. Neurochem. 19, 577-583.

GRAFSTEIN B. (1967) Science, N.Y. 157, 196-198.

GrafsteIN B. (1971) Science, N.Y. 172, 177-179.

GRAFSTEIN B., Forman D. S. \& MCEWEN B. S. (1972) Expl Neurol. 34, 158-170.

Grafstein B. \& LaURENo R. (1973) Expl Neurol. 39, 44-57.

Grafstein B., Murray M. \& Ingoglia N. A. (1972) Brain Res. 44, 37-48.

GRAND R. J. (1969) Biochim. Biophys. Acta 195, 252-254.

HENDRICKSON A. E., WAGoner N. \& COWAN W. M. (1972) Z. Zellforsch. 135, 1-26.

HIDER R. C., FERN E. B. \& LONDON D. R. (1971) Biochem. J. 121, 817-827. 
JohNSON L. W. \& VELICK S. F. (1972) J. biol. Chem. 247, 4138-4143.

KARLSSON J. \& SJöSTRAND J. (1972) Brain Res. 37, 279-285.

KIPNIS D. M., REIS E. \& HELMREICH E. (1961) Biochim. biophys. Acta 51, 519-524.

KUNZLE H. \& Cuenod M. (1973) Brain Res. 62, 213-217.

LAJTHA A. (1964) Int. Rev. Neurobiol. 6, 1-98.

LAJTHA A. \& MARKS N. (1971) Handbook of Neurochemistry (LAJTHA A. ed.) Vol. 5B, Chap. 18. Plenum Press, New York.

LaVail J. H. \& LaVail M. M. (1972) Science, N.Y. 176, 1416-1417.

LOWRY O. H., Rosenbrough N. J., FARR A. L. \& RANDALl. R. J. (1951) J. biol. Chem. 193, 265-275.

Mans R. J. \& Novelli G. D. (1961) Archs Biochem. Biophys. 94, 48-53.

MCEWEn B. S., Forman D. S. \& Grafstein B. (1971) J. Neurobiol. 2, 361-377.

MCEWEn B. S. \& GRAFStein B. (1968) J. Cell Biol. 58, 494-508.

Neale J. H., Neale E. A. \& Agranoff B. W. (1972) Science, N.Y. 176, 407-410.
OLDENDORF W. H. (1971) Am. J. Physiol. 221, 1629-1639.

Paulson J. C. \& MCClure W. O. (1973) Molec. Pharmac. 9, 41-50.

Phillips A. M. (1969) in Fish Physiology (HoAR W. S. \& Randall D. J., eds.) Vol. 1, p. 391. Academic Press, New York.

Poole B. (1971) J. biol. Chem. 246, 6587-6591.

Reynolds E. W. (1963) J. Cell Biol. 17, 208-212.

Robertson J. D., Bodenheimer T. S. \& Stage D. E. (1963) J. Cell Biol. 19, 159-199.

SAlPETER M. M. \& BACHAMnN L. (1964) J. Cell Biol. 22, $469-477$.

Salpeter M. M., BachmanN L. \& SAlpeter E. E. (1969) J. Cell Biol. 41, 1-20.

SCHIMke R. T. \& DOYLE D. (1970) Ann. Rev. Biochem. 39, 929-976.

Sotelo C. \& Palay S. L. (1968) J. Cell Biol. 36, 151-179.

TAYlor A. C. \& Weiss P. (1965) Proc. natn. Acad. Sci., U.S.A. 54, 1521-1527.

VAN VenRoOIJ W. J., POORT C., KRAMER M. F. \& JANSEN M. T. (1972) Eur. J. Biochem. 30, 427-433.

Yudilevich D. L., De Rose N. \& Sepulveda F. V. (1972) Brain Res. 44, 569-578. 